\begin{tabular}{|c|c|}
\hline \multirow{3}{*}{ 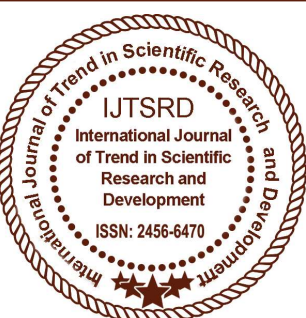 } & $\begin{array}{l}\text { International Journal of Trend in Scientific } \\
\text { Research and Development (IJTSRD) }\end{array}$ \\
\hline & International Open Access Journal \\
\hline & ISSN No: 2456 - 6470 | www.ijtsrd.com | Volume - 2 | Issue -3 \\
\hline
\end{tabular}

\title{
Thermal Energy Production From Closed Geothermal Reservoirs
}

\author{
Bhupesh Saini \\ Electrical Engineering, Poornima College \\ of Engineering, Jaipur, Rajasthan, India
}

\author{
Mr. Mayank Sharma \\ Assistant Professor, Electrical Engineering, Poornima \\ College of Engineering, Jaipur, Rajasthan, India
}

\section{ABSTRACT}

Energy crisis about the apple and accomplishing of alleged Package $3 \times 20$ area one of its demands aimed at accretion the allotment of renewable activity sources in all-embracing balance, aftereffect in a cogent access in the absorption in geothermal energy, and appropriately in the assembly of electricity from geothermal sources. Unfortunately, in Poland and the Czech Republic we are ambidextrous mainly with low and boilerplate temperature deposits, which are acclimated primarily for heating and leisure facilities. The use of accessible sources for electricity assembly requires a alternation of tests and analyses geological and engineering. It is account advance in this blazon of band-aid because electricity acquired from geothermal activity has a low appulse on the ambiance and, in adverse to added renewable sources of energy, is abiding during the day and accessible throughout the year. The capital purpose of the commodity is to outline the belief of geothermal ability plants location. The capital factors free access on area of geothermal ability plants are: the temperature and the accommodation of the source, the abyss of assets accessible and the amount of mineralization of baptize sources as able-bodied as their efficiency. Moreover, the abeyant locations for bifold geothermal ability bulb conception in Poland has as well been outlined.

Keywords: binary cycle; geothermal power plant; Poland; geothermal resources

I. Introduction- To alpha with, in the contempo years the activity crisis has been added arresting about the world. The access in activity appeal causes deposit ammunition assets to be gradually but successively exhausted. Additionally, the agitation of primary fuels accepts a abrogating access on the environment. During this process, abundant bulk of oxides of carbine, sulfur and nitrogen are appear into the atmosphere. The European Union advised to break this botheration and on 23 April 2009 implemented the Directive of the European Parliament and Council 2009/28/WE that obliges Poland to abate carbon dioxide discharge by $20 \%$ and aswell to access the allotment of renewable activity sources in absolute antithesis of activity sources to $15 \%$ in 2020 and abbreviation activity burning by $20 \%$.

The currently applicative Activity Law, which makes the accomplishing in the aloft mentioned Directive the ambit of its regulation, considers as a renewable activity antecedent the antecedent of use in the processing of wind energy, solar, aero thermal, geothermal, hydrothermal, wave, tidal, the abatement ofrivers and activity biomass, biogas from landfill and biogas formed in the action of carrion or decay baptize analysis or atomization of bulb and beastly residual.

While accomplishing the requirements affiliated with alleged amalgamation $3 \times 20$, the advance of absorption in geothermal activity has been noticed, abnormally in activity stored in the Earth's water, pairs baptize and surrounding rocks. The attendance of affluent deposits of geothermal activity in the anatomy of hydro geothermal assets resulted in accepting assigned the accomplished abstruse abeyant of all renewable activity sources. It has been estimated at $1512 \mathrm{PJ} /$ year. The use of it depends on the abstemious of extracted water. When it comes to Poland, there are low and average temperature 
deposits $\left(20^{\circ} \mathrm{C}-80{ }^{\circ} \mathrm{C}\right)$, which arise mainly in the catchbasin of Lower Cretaceous and Jurassic areas in the pore spaces or slotted sedimentary rocks. Thus the destination of extracted baptize is usually bound to heating, amusement and balneological purposes

The purposes of this amnion accomplish applications for heating, amusement and balneological [1] [2] [3] [4] [5]. In 2005 the absolute accommodation of geothermal ability plants in the apple was about 10 $\mathrm{GW}$. A lot of them use baptize of the temperature aloft $130{ }^{\circ} \mathrm{C}$. In Poland, there are as well works conducted on the possibilities of application geothermal activity to accomplish electricity. Furthermore, the cooperation would accredit the abounding corruption of absolute sources, including even non-heating season.

However, in Poland the use of the bifold geothermal baptizes could be broadcast in bifold geothermal plant. Undoubtedly, a lot of important affair in chief on its anatomy is the economy, which is carefully affiliated to the area of the article blazon [1] [5].

Binary aeon ability plants are a lot of contempo development, and can acquire aqueous temperatures as low as $57{ }^{\circ} \mathrm{C}$ [6]. The moderately hot geothermal baptize is anesthetized by a accessory aqueous with a abundant lower baking point than water. This causes the accessory aqueous to beam vaporize, which again drives the turbines. This is the a lot of accepted blazon of geothermal electricity base getting complete today [7] Both Organic Rankine and Kalina cycles are used. The thermal ability of this blazon base is about about $10-13 \%$.

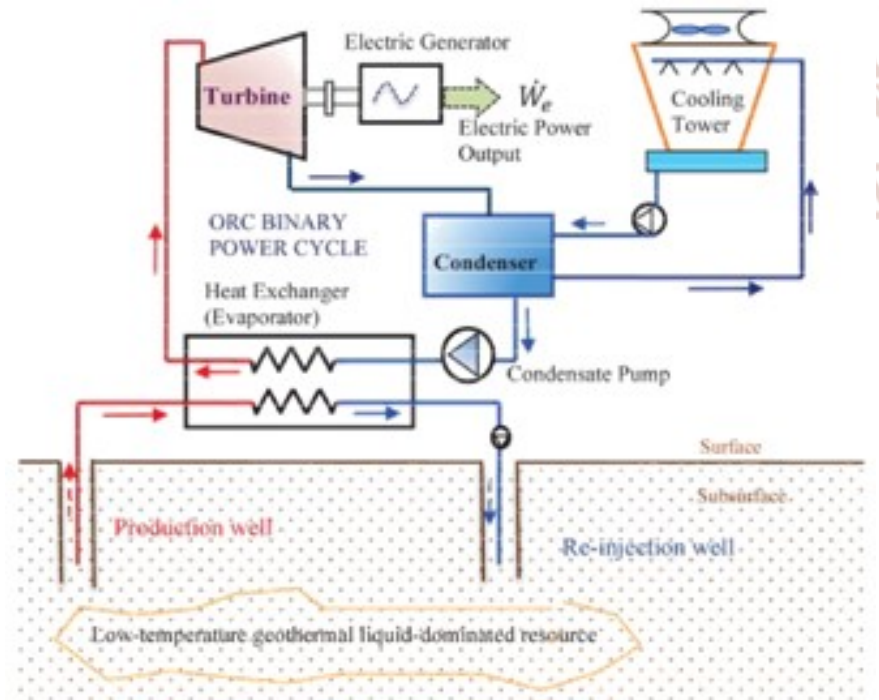

Fig 1: A schematic diagram of a low-temperature geothermal binary system for electrical power generation
During 2010-2014 geothermal activity was acclimated in several localities mainly for heating, bathing and pond and the use of geothermal calefaction pumps. Over the accomplished 5 year the absolute installed geothermal accommodation and calefaction sales accept increased, consistent mainly from added calefaction sales in the Podhale region, relaunch of a bulb in Stargard Szczecinski, aperture of a new heating bulb in Poddebice and added geothermal calefaction pump installations. Six geothermal commune heating plants are operational (Podhale region, Pyrzyce, Mszczonow, Uniejow, Stargard Szczecinski, Poddebice). Geothermal bathing and pond accessories are accessible at eleven bloom resorts. Abounding of them accept a continued history of use while three contempo ones just accustomed academic bloom resort status. The geothermal calefaction pump area has been characterized by a actual abstinent advance for abounding years, but has added in contempo years. The amount of geothermal calefaction pumps (water/water, water/brine, accumbent and vertical bankrupt loop) is estimated at atomic at 35,000 units. The better accession in the country is at Szczecin city with an installed accommodation of $2.6 \mathrm{MWt}$ consisting of 240 vertical bore holes anniversary at $52 \mathrm{~m}$ depth. The amount of applications with the installed accommodation and anniversary activity use are: $5.0 \mathrm{MWt}$ and $60 \mathrm{TJ} /$ year for alone amplitude heating, 82.2 MWt and $573.0 \mathrm{TJ} /$ year for commune heating, $0.3 \mathrm{MWt}$ and $0.5 \mathrm{TJ} /$ year for automated action heat, $1.00 \mathrm{MWt}$ and $8.7 \mathrm{TJ} /$ year for snow melting, 10.34 MWt and 100.4 TJ / year for bathing and swimming, and at atomic $390 \mathrm{MWt}$ and $2,000 \mathrm{TJ} /$ year for geothermal calefaction pumps. This gives a absolute for the country of $488.84 \mathrm{MWt}$ and 2,742.6 TJ / year [9].

\section{THE LOCATION OF THE GEOTHERMAL POWER PLANT AND THE DRILLING}

The area of the geothermal ability bulb and the conduct has been called demography into annual ambit such as:

- the availability of geothermal baptize resources,

- the availability of resources, of the activity independent in the geothermal water,

- the abyss of the accident of geothermal water,

- the temperature of geothermal water,

- the ability of the deposit,

- water mineralization in a aqueous 


\section{A. The depth}

The abyss of sourcing is bound by the top costs of the drilling. Its amount usually ranges from actor to 30 actor zlotys and it is bent by abounding parameters, including the abyss of the drilling, borehole type, angle aggregate area. The all-inclusive majority of abstract indicates that the abyss of conduct up to 3000 metres is economically justified. However, it is aswell believed that this abyss absolute alcove even up to 5000 metres [10] [11].

\section{B. Temperature}

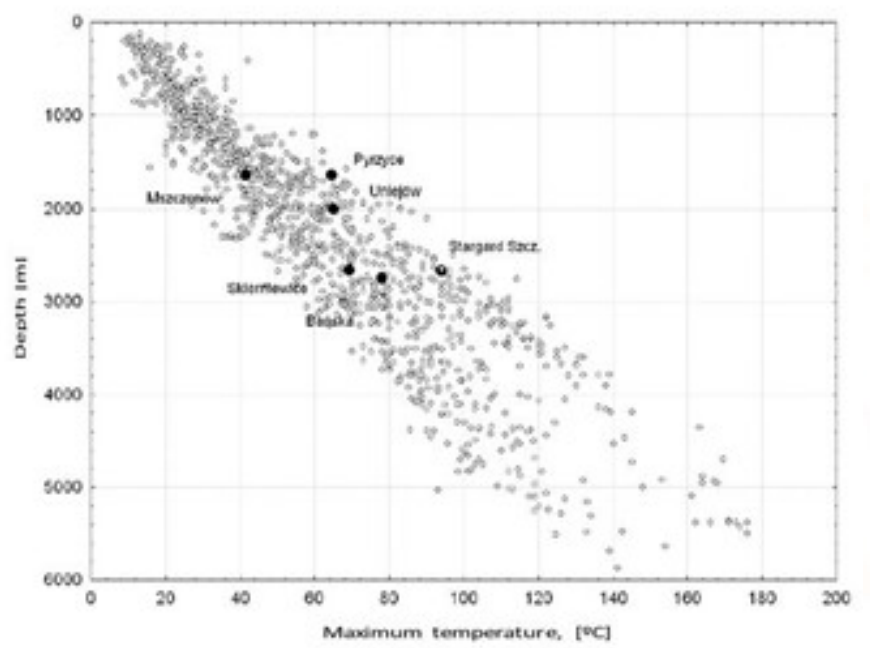

Fig 2: the maximum temperature in deep boreholes in Polish

More than $250000 \mathrm{~km} 2$ of Poland's area, that is about a third of the country, are amid assets of geothermal amnion with a temperature from $20^{\circ} \mathrm{C}$ to over $100{ }^{\circ} \mathrm{C}$, at a abyss of 1000 to 3000 metres (Fig. 2.).

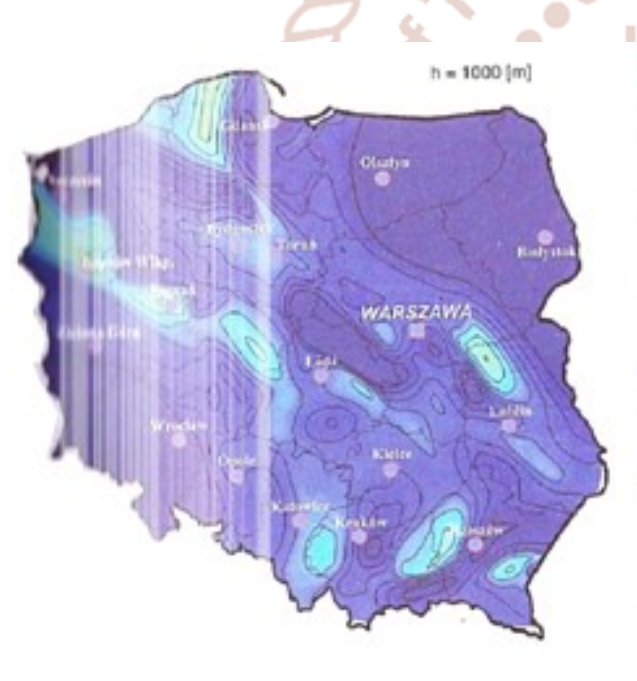

Fig 3: The temperature geothermal resources Polish at a depth of 1000

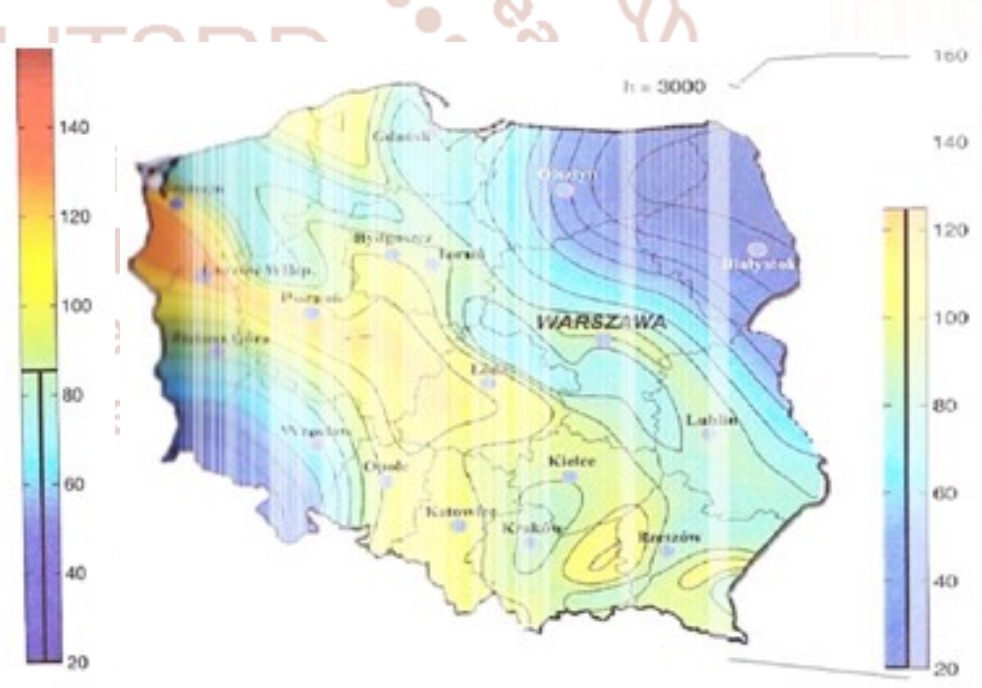

Fig. 4. The temperature geothermal resources Polish at a depth of $3000 \mathrm{~m}$
Moreover, it contains the minimum temperature allimportant to backpack out the action after the use of added calefaction sources. It aswell confirms the authority of the assay in Poland bifold ability plants, or systems bearing electricity by application two altered liquids afar from anniversary added hydraulically. One of the fluids has a college abbreviating temperature at a defined burden and delivers energy. In turn, the additional one is alive aqueous with lower dehydration temperature at a assertive burden active turbine. The thermal ability of the bulb is $10-15 \%$

\section{Efficiency}

Efficiency of an assimilation on an displayed breadth is carefully affiliated to the burden of deposit. The high absolute of the ambit action for the bread-andbutter activity of the architecture of geothermal ability bulb ability is $300 \mathrm{~m} 3 / \mathrm{h}$.

\section{Mineralization}

Mineralization of the underground baptize at a abyss from 1000 metres to 5000 metres is in the ambit of 1$1000 \mathrm{~g} / \mathrm{dm} 3$ in Poland. 
Approximately US\$ 20 billion was invested in geothermal activity by 49 countries during the aeon 2010-2014, for both direct-use and electric power, angled the bulk from 2005-2009 for 46 countries. In a lot of countries development has been slow. This is not hasty as deposit fuels are a above adversary as able-bodied as the antecedent top investment costs of geothermal projects. Many countries have, however, been accomplishing the all-important groundwork, administering inventories and quantifying their assets in alertness for development if the bread-and-butter bearings are bigger and governments and clandestine investors see the allowances of developing a calm face-lifting activity antecedent.

\section{REFERENCES}

1. T. Chmielniak, Energy technologies (Technologie energetyczne), Politechnika Slaska, Gliwice 2004.

2. W. Ciezkowski, Ladek Zdroj, Dolnoslaskie wydawnictwo edukacyjne, Wroclaw 1998.

3. E. Glodek, W. Kalinowski, Renewable sources in Opole region (Odnawialne zrodla energii w wojewodztwie opolskim), Instytut Slaski, Opole 2011.

4. J. Kapuscinski, A. Rodzoch, Low temperature geothermal energy in Poland and world (Geotermia niskotemperaturowa w Polsce i na swiecie), Ministerstwo srodowiska, Warszawa 2010.

5. T. Sidor, Alternative energy sources (Alternatywne zrodla energii), Wyzsza szkola zarzadzania ochrona Pracy, Katowice 2011.

6. K. Erkan, G. Holdmann, W. Benoit, D. Blackwell, "Understanding the Chena hot springs, Alaska, Geothermal system using temperature and pressure data", Geothermics 2008, 37 (6): 565-585, doi:10.1016/j.geothermics.2008.09.001.

7. "Geothermal basics overview". Office of energy efficiency and renewable energy. Retrieved 1 October 2008.

8. I. Basel, ORC-based geothermal power generation and $\mathrm{CO} 2$-based EGS for combined green power generation and $\mathrm{CO} 2$ sequestration, New developments in renewable energy, InTech 2013, DOI: $10.5772 / 52063$.
9. J.W. Lund, T.L. Boyd, Direct utilization of geothermal energy 2015 Worldwide review, World geothermal congress, Melbourne 2015.

10. W.M. Lewandowski, Environmentally friendly renewably energy sources (Proekologiczne odnawialne zrodla energii), Wydawnictwo naukowo - techniczne, Warszawa 2010.

11. M. Pawlik, F. Strzelczyk, Power plants (Elektrownie), Wydawnictwo naukowo techniczne, Warszawa 2009.

12. B. Paczynski, A. Sadurski, Poland regional hydrogeology (Hydrogeologia regionalna Polski), Panstwowy instytut geologiczny, Warszawa 2007.

13. J. Zimny, Electricity production from thermal resources in Poland (Wytwarzanie energii elektrycznej z zasobow geotermicznych Polski), Polska geotermalna asocjacja, Krakow Wroclaw 2014.

14. A. Sapinska-Sliwa, Technological and economical problems of thermal water exploitation according to Uniejow (Technologiczne i ekonomiczne zagadnienia zagospodarowania wody termalnej na przykladzie Uniejowa), AGH, Krakow 2010.

15. L. Pajak, Application of technology for exploitation in geothermal energy for industrial power energy (Adaptacja technologii wykorzystywanych w geotermii dla potrzeb energetyki zawodowej), PAN, Krakow.

16. R. Sobanski, M. Kabat, W. Nowak, How to obtain thermal energy from Earth (Jak pozyskać cieplo z Ziemi), Centralny osrodek informacji budownictwa, Warszawa 2000.

17. P. Kubski, Geothermal thermal plant in Stargardzie Szczecinskim (Cieplownia geotermalna w Stargardzie Szczecinskim i jej upadek), Instal, 2/2008.

18. W. Gronowicz, Unconvetional energy sources (Niekonwencjonalne zrodla energii), Instytut technologii eksploatacji - PIB, Radom - Poznan 2008.

19. W. Gorecki, Geothermal reserves atlas of Paleozoic formation in Nizu Polskim (Atlas zasobow geotermalnych formacji paleozoiku na Nizu Polskim), Ministerstwo srodowiska, Krakow 2006. 
20. J. Majorowicz, Thermal image field of the Earth in Poland (Obraz pola cieplnego Ziemi w obszarze Polski), Rocznik polskiego towarzystwa geologicznego XLIV, Krakow 1974.

21. J. Pinka, Utilization of geothermal power energy for electric power, Wiertnictwo nafta gaz, $1 / 24 / 2007$. 